\title{
ANALISIS KINERJA AGRIBISNIS PADI ORGANIK PETANI BINAAN JAMTANI DI KABUPATEN PANGANDARAN
}

\author{
PERFORMANCE ANALYSIS OF ORGANIC RICE AGRIBUSINESS \\ JAMTANI DEVELOPMENT FARMERS IN PANGANDARAN REGENCY
}

\author{
Mai Fernando Nainggolan*¹, Iwan Setiawan ${ }^{2}$, dan Trisna Insan Noor ${ }^{2}$, Tualar \\ Simarmata $^{2}$, Kustiwa Adinata ${ }^{3}$, Silke Stoeber ${ }^{4}$ \\ ${ }^{1}$ Pascasarjana Ekonomi Pertanian, Fakultas Pertanian, Universitas Padjadjaran \\ ${ }^{2}$ Dosen Fakultas Pertanian, Universitas Padjadjaran \\ ${ }^{3}$ Jaringan Masyarakat Tani Indonesia \\ ${ }^{4}$ Humbolt University \\ E-mail: andonainggolan88@gmail.com \\ (Diterima 15-08-2021; Disetujui 15-12-2021)
}

\begin{abstract}
ABSTRAK
Meskipun pertanian organik yang salah satunya adalah padi organik telah disebutkan banyak manfaat dan pengaruh positifnya, namun jika diamati perkembangannya masih belum mencapai produksi yang maksimal. Tujuan penelitian ini adalah mendeskripsikan kinerja subsistem agribisnis dalam pengembangan agribisnis padi organik pada petani. Penelitian ini dilaksanakan di beberapa kelompok tani yang menjadi binaan JAMTANI yang tersebar di desa Cimurutu, Paledah, dan Padaherang yang merpakan petani padi organik di wilayah tersebut. Teknik pengambilan sampel yang digunakan pada penelitian ini yaitu menggunakan teknik cluster random sampling dengan jumlah responden sebanyak 120 petani yang dibina oleh JAMTANI. Kinerja dianalisis menggunakan statistik deskriptif. Hasil penelitian berdasarkan pendekatan sistem agribisnis yang terdiri atas subsistem penyediaan input, budi daya, penanganan panen dan pascapanen, pemasaran dan penunjang menunjukkan bahwa kinerja agribisnis padi organik pada petani mitra JAMTANI di kabupaten Pangandaran memperoleh kinerja cukup. Perubahan produksi jika dilihat dari jumlah petani, sebanyak 120 orang pernah mengalami perubahan jumlah produksi.
\end{abstract}

Kata kunci: padi, organik, JAMTANI

\section{ABSTRACT}

Although organic farming, one of which is organic rice, many benefits and positive effects have been mentioned, if we observe the development, it has not yet reached its maximum production. The purpose of this study was to describe the performance of the agribusiness subsystem in the development of organic rice agribusiness for farmers. This research was carried out in several farmer groups assisted by JAMTANI spread across the villages of Cimurutu, Paledah, and Padaherang who are organic rice farmers in the area. The sampling technique used in this research is using cluster random sampling technique with the number of respondents as many as 120 farmers who are fostered by JAMTANI. Performance was analyzed using descriptive statistics. Research results Based on the agribusiness system approach consisting of input supply subsystems, cultivation, harvest and postharvest handling, marketing and support, it shows that the performance of organic rice agribusiness on JAMTANI partner farmers in Pangandaran district obtained adequate performance. Changes in production when viewed from the number of farmers, as many as 120 people have experienced changes in the amount of production.

Keywords: rice, organic, JAMTANI 


\section{PENDAHULUAN}

Indonesia merupakan negara agraris yang salah satu produksi adalah tanaman padi. Padi merupakan tanaman pangan yang menjadi salah satu kebutuhan paling mendasar di Indonesia, sehingga ketersediaan padi bagi masyarakat sangat penting. Kebutuhan beras nasional dapat dipenuhi dengan mengupayakan keseimbangan antara laju kebutuhan beras dengan kenaikan produksi secara nasional (Zakiyah dan Supriono, 2019). Pada tahun 2018 pemerintah Malaysia mencoba mengendalikan laju kebutuhan beras dengan mempromosikan makanan pokok lain sebagai sumber karbohidrat dan hasilnya Malaysia mampu mengurangi impor beras sampai 10\% (Omar et al, 2019). Di Laos, pada tahun 2014 pemerintah berusaha meningkatkan produksi beras melalui perluasan area tanam dan rehabilitasi irigasi sehingga pada tahun 2015-2018 kebutuhan beras di negara tersebut dapat terpenuhi bahkan diperkirakan telah mengekspor rata-rata 300.000 ton beras setiap tahunnya (FAO, 2020).

Efisiensi pertanian padi dan meningkatkan pendapatan petani perlu dikembangkan suatu inovasi yang baru ke tengah masyarakat seperti pertanian berbasis organik. Tujuan sistem usaha tani ekologis atau pertanian organik adalah memperhatikan kembali pentingnya dasar-dasar ekologis pada sistem pertanian yang ada. Pertanian organik telah diusulkan sebagai sarana penting untuk mengurangi dampak negatif terhadap linkungan. Menurut Surekha, et al (2013), pertanian organik dapat memecahkan semua masalah di atas dan pertanian organik diharapkan menjadi pilihan terbaik untuk melindungi/mempertahankan kesehatan tanah, dan mendapatkan banyak hal penting di bidang pertanian saat ini.

Salah satu usahatani padi organik yang umum dikembangkan sekarang ini dikenal dengan System of Rice Intensification (SRI Organik). Teknologi budidaya SRI diperkenalkan sebagai upaya mencari jalan keluar dari sistem budidaya konvensional yang dibawa oleh revolusi hijau. SRI yang dikembangkan di Jawa Barat adalah SRI organik yang menekankan pada penggunaan pupuk organik untuk memperbaiki kesuburan tanah.

Berdasarkan Peraturan Daerah Provinsi Jawa Barat Nomor 22 Tahun 2010 tentang Rencana Tata Ruang Wilayah (RTRW) Tahun 2009-2029, wilayah Provinsi Jawa Barat terbagi ke 
dalam 6 (enam) Wilayah Pengembangan (WP), yang salah satunya adalah WP Priangan Timur dan Pangandaran, meliputi Kabupaten Garut, Kabupaten Tasikmalaya, Kabupaten Ciamis, Kota Tasikmalaya, Kota Banjar, dan Kabupaten Pangandaran. Wilayah ini memiliki potensi pengembangan dalam sektor pertanian, perkebunan, perikanan tangkap, pariwisata, industri pengolahan dan pertambangan mineral (RPJMD, 2016).

Salah satu lembaga yang memberikan perhatian khusus pada wilayah ini adalah Jaringan Masyarakat Tani Indonesia (JAMTANI) terutama dalam mendukung pertanian organik. Hal ini dikarenakan salah satu misi lembaga ini adalah untuk mendukung pertanian yang ramah lingkungan sehigga dapat menekan efek perubahan iklim yang disebabkan oleh pertanian. Dalam perkembangannya, JAMTANI sangat dipengaruhi oleh organisasi Ikatan Petani Pengendalian Hama Terpadu (IPPHTI). Tujuan utama yang diharapkan dari penelitian yang dilakukan ini adalah mendeskripsikan kinerja subsistem agribisnis dalam pengembangan agribisnis padi organik pada petani padi organik binaan JAMTANI di Kabupaten Pangandaran.

\section{METODE PENELITIAN}

Metode penelitian ini menggunakan desain kuantitatif dapat diartikan sebagai metode penelitian yang berlandaskan pada filsafat positivism. Penelitian ini dilaksanakan di beberapa kelompok tani yang menjadi binaan JAMTANI yang tersebar di desa Cimurutu, Paledah, dan Padaherang yang merupakan petani padi organik di wilayah tersebut. Penentuan lokasi penelitian dilakukan dengan sengaja (Pusposive Sampling) karena pertimbangan bahwa lokasi merupakan daerah yang menjadi binaan dan juga daerah yang memproduksi padi organik. Sumber data yang digunakan dalam penelitian ini yaitu data primer dan data sekunder. Teknik pengambilan sampel yang digunakan pada penelitian ini yaitu menggunakan teknik cluster random sampling dengan jumlah responden sebanyak 120 petani yang dibina oleh JAMTANI.

Analisis kinerja sistem agribisnis dan keberlanjutan agribisnis padi organik pada petani binaan JAMTANI di kabupaten Pangandaran dilaksanakan dengan metode deskriptif yang diaplikasikan untuk menggambarkan karakteristik petani dan kinerja masingmasing subsistem dalam sistem agibisnis padi organik. Data yang dianalisis secara 
deskriptif disajikan dalam suatu paragraf secara naratif dilengkapi dengan tabulasi sederhana berdasarkan hasil jawaban petani.

Pengukuran kinerja dapat didefinisikan sebagai proses efisiensi dan efektifitas dari tindakan yang lalu. Ukuran kinerja dapat didefinisikan sebagai sebuah parameter yang digunakan untuk mengkuantifikasi efisiensi atau efektivitas dari tindakan yang lalu. Matriks kinerja adalah definisi dari cakupan, isi dan bagian-bagian komponen dari sebuah ukuran kinerja yang berbasis luas (Kennerley dan Neely,2002). Tahap persiapan pengukuran kinerja dimulai dari penentuan indikator. Setiap indikator yang ditentukan harus didukung dengan kriteria sebagai penentu apakah kinerja yang dihasilkan baik atau tidak baik, maka akan sama seperti penentuan skala petani yaitu digunakan kriteria garis kontinum, yang membagi tanggapan petani menjadi 5 kategori (Sangat baik, Baik, Cukup, Kurang baik dan Tidak baik). Pengkategorian dilakukan berdasarkan nilai rata-rata jawaban petani dengan cara sebagai berikut:

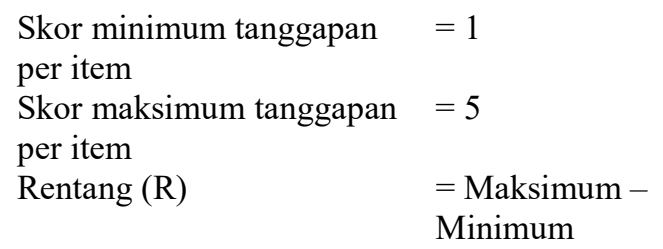

$$
\begin{array}{ll} 
& =5-1=4 \\
\text { Banyak kategori }(\mathrm{K}) & =5(\text { Sangat baik, } \\
& \text { Baik, Cukup, } \\
& \text { Tidak baik dan } \\
& \text { sangat baik) } \\
& =\mathrm{R} / \mathrm{K} \\
\text { Panjang interval } & =4 / 5=0,80
\end{array}
$$

Maka diperoleh interval kategori sebagai berikut:

$\begin{array}{ll}1.00-1.80 & =\text { Sangat tidak baik } \\ 1.81-2.60 & =\text { Tidak baik } \\ 2.61-3.40 & =\text { Cukup baik } \\ 3,41-4,20 & =\text { Baik } \\ 4,21-5,00 & =\text { Sangat baik }\end{array}$

Setelah menentukan kriteria didapatkan 5 kriteria pengukuran kinerja, kriteria tersebut akan dirubah satuannya ke dalam persentase. Hal tersebut dilakukan agar mempermudah pembaca dalam memahami seberapa baik kinerja yang dihasilkan pada penelitian ini, yaitu kinerja sistem agribisnis dan kinerja keberlanjutan agribisnis padi organik pada petani binaan JAMTANI di kabupaten Pangandaran. Sistem pengukuran kinerja memungkinkan informasi yang dibuat berdasarkan keputusan yang disepakati karena ini mengkuantifikasikan efisiensi dengan efktivitas dari tindakan yang lalu melalui akuisisi, pembandingan, pensortasian, analisis, dan interpretasi dari data yang layak (Kennerly dan Neely, 2002). Dalam koteks ini, aktivitas pemrosesan informasi yang meliputi memperoleh, membandingkan, menyortir, 
menganalisis, dan menginterpretasikan. Dilihat dari penjelasan tersebut, maka peneliti bisa menentukan satuan pengukuran kinerja asalkan memenuhi syarat yang telah ditentukan. Perubahan satuan ke dalam persentase dilakukan dengan membagi hasil indeks rata-rata petani dengan jumlah kategori yang telah ditentukan yaitu 5 kategori lalu dikalikan dengan 100\%. Maka indeks rata-rata yang dihasilkan akan memiliki satuan dalam bentuk persentase. Diperoleh interval kategori kinerja dalam bentuk persentase sebagai berikut:

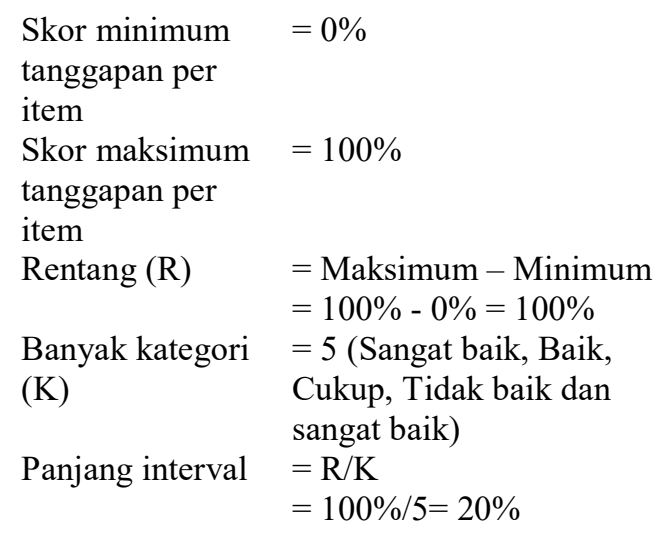

Maka diperoleh interval kategori sebagai berikut:

$$
\begin{array}{ll}
0 \%-20 \% & =\text { Sangat tidak baik } \\
21 \%-40 \% & =\text { Tidak baik } \\
41 \%-60 \% & =\text { Cukup baik } \\
61 \%-80 \% & =\text { Baik } \\
81 \%-100 \% & =\text { Sangat baik }
\end{array}
$$

\section{HASIL DAN PEMBAHASAN}

Kinerja atau performance merupakan hasil atau keluaran dari suatu proses (Sutrisno, 2016). Menurut pendekatan perilaku dalam manajemen, kinerja adalah kuantitas atau kualitas sesuatu yang dihasilkan atau jasa yang diberikan oleh seseorang yang melakukan pekerjaan (Luthans, 2005). Kinerja pengembangan agribisnis padi organik di wilayah Kabupaten Pangandaran yang meliputi desa dampingan JAMTANI dijelaskan dengan menggunakan analisis deskriptif yang diolah dengan cara dikelompokkan dan ditabulasikan menggunakan angka frekuensi dan persentase, serta kemudian diberi penjelasan naratif guna memberikan gambaran empiris atas data primer yang telah dikumpulkan dari responden petani padi organik. Analisis deskriptif dilakukan untuk mengetahui variabel mandiri, baik satu variabel atau lebih (independen), tanpa membuat perbandingan atau menghubungkan dengan variabel yang lain. Status kinerja pengembangan agribisnis padi organik dibahas dengan menggunakan pendekatan sistem agribisnis yang terdiri atas subsistem input produksi, subsistem produksi/on-farm, subsistem penanganan dan pengolahan, subsistem pemasaran dan subsistem sarana penunjang.

\section{Kinerja Input Produksi}

Kinerja subsistem input produksi dilihat dari variabel pupuk organik, bibit padi, pestisida organik, dan sumber air 
irigasi. Kinerja subsistem dihitung berdasarkan perolehan indeks rataratanya. Hasil analisis secara umum kinerja subsistem input produksi dapat dilihat Gambar 1.

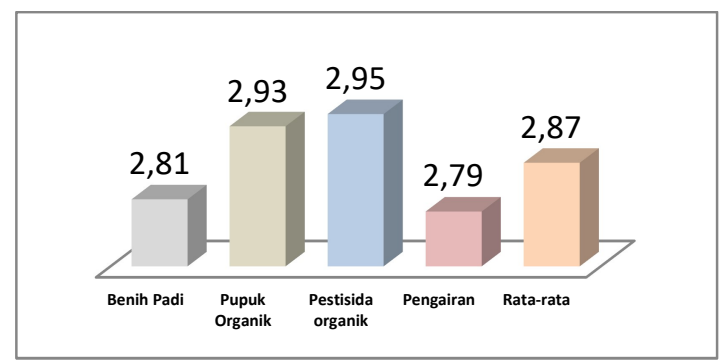

Gambar 1. Kinerja Subsistem Input Produksi berdasarkan Perolehan Indeks Rata-rata Pada Agribisnis Padi Organik Binaan JAMTANI di wilayah Kabupaten Pangandaran

Berdasarkan Gambar 1 tersebut diketahui bahwa secara umum, total skor kinerja subsistem input produksi berdasarkan perolehan indeks rata-rata pada agribisnis Padi Organik Binaan JAMTANI di wilayah Kabupaten Pangandaran memperoleh tingkatan kinerja cukup baik. Kinerja subsistem input produksi terkait dengan pestisida nabati yang digunakan para petani memperoleh kinerja baik dan sesuai dengan prinsip-prinsip pertanian organik. Hal ini dapat dilihat dari kebiasaan petani dalam praktik budidaya padi organik yang hanya menggunakan pestisida hayati/nabati untuk memberantas hama dan penyakit tanaman padi organik dengan kemudahan dalam pelaksanaan teknis pemberantasan menggunakan pestisida nabati dengan biaya murah, kemudahan dalam proses pembuatann pestisida nabati, dan bahan baku yang digunakan untuk pembuatan pestisida hayati/nabati sangat mudah diperoleh di lingkungan setempat.

Semua petani padi organik melaksanakan pemberantasan hama dan penyakit hanya menggunakan pestisida nabati/organik. Pestisida nabati dibuat sendiri oleh para petani dengan cara memanfaatkan daun Mindi, daun Suren dan Kirinyuh (sunda) dengan cara masing-masing jenis tanaman tersebut diambil daunnya sebanyak satu kepalan tangan (25 gram) kemudian ditumbuk sampai halus, ditambahkan satu gelas air putih dan disaring. Air saringan disimpan selama 1 (satu) malam dan kemudian besoknya dapat diaplikasikan. Aplikasi dilakukan dengan menggunakan alat semprot/sprayer. Formulasi di berbagai wilayah berbeda tergantung ketersediaan bahan baku nya, formulasi lainnya yang dilakukan diantaranya campuran daun Suren dicampur tembakau dengan perbandingan 2:1.

Kinerja subsistem input produksi terkait dengan sumber air irigasi yang digunakan untuk pengairan lahan sawah padi organik termasuk kategori kinerja baik. Para petani telah melakukan 
pemisahan sumber air irigasi untuk pertanamannya dengan pertanian padi konvensional dengan kinerja sangat baik dan tujuan pemisahan adalah untuk menghindari kontaminasi dengan bahanbahan kimia termasuk kategori kinerja baik. Namun, dalam praktiknya masih banyak petani yang merasakan kesulitan pada saat memenuhi syarat untuk melaksanakan pemisahan antara lahan pertanian padi organik dengan lahan padi konvensional sehingga kinerjanya kurang. Hal ini sesuai dengan pendapat Amaliah (2015) bahwa pada saat ini kondisi sumber air di sentra pertanian telah tercemar bahan anorganik dan kondisi ini menjadi masalah bagi petani organik, karena untuk mendapatkan air yang bebas bahan pencemar harus dilakukan dengan cara (1) mencari sumber air alternatif seperti sumur bor, (2) membuat saluran air dari bagian hulu sungai, (3) mengolah air terlebih dahulu dengan cara mengendapkan atau memberi perlakukan agar dihasilkan air yang sudah tidak tercemar.

\section{Kinerja Produksi/On-farm}

Kinerja subsistem produksi/on-farm yang dibahas terdiri atas periode konversi, tenaga kerja, teknologi budidaya dan kontinuitas produksi. Kinerja subsistem dihitung berdasarkan perolehan indeks rata-ratanya. Hasil secara umum kinerja subsistem produksi/on-farm dapat dilihat pada Gambar 2.

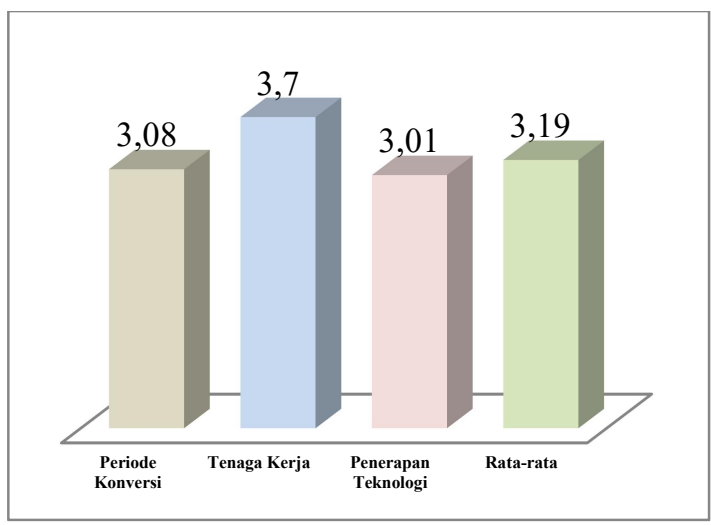

Gambar 2. Kinerja Subsistem Produksi/Onfarm berdasarkan Perolehan Indeks Rata-rata Pada Agribisnis Padi Organik binaan JAMTANI di Kabupaten Pangandaran

Berdasarkan Gambar 2 tersebut diketahui bahwa secara umum, total skor kinerja subsistem produksi/on-farm berdasarkan perolehan indeks rata-rata pada Agribisnis Padi Organik binaan JAMTANI di Kabupaten Pangandaran memperoleh tingkatan kinerja yang cukup baik. Periode konversi menunjukkan kinerja yang baik di wilayah penelitian hal ini karena sudah ada kelompok tani yang telah melaksanakan sertifikasi padi organik. Sehingga para petani di wilayah ini telah sangat memahami bahwa agar lahan padi organik yang diusahakan terbebas dari kontaminasi dan residu kimia memerlukan waktu konversi yang idealnya minimal 2 tahun. Informasi ini 
diperoleh dari berbagai penyuluhan/ pelatihan yang diberikan oleh berbagai lembaga/dinas/perusahaan. Namun petani merasakan bahwa masa konversi itu terlalu lama untuk dilalui, petani harus melakukan berbagai aktivitas yang menyita waktu, perhatian dan tenaga ekstra agar memenuhi syarat tersebut. Apabila memungkinkan petani berharap periode konversi dikurangi dan produk yang dihasilkan dapat diklaim organik Kinerja subsistem produksi/on-farm yang berhubungan dengan periode konversi dari pertanian konvensional ke pertanian padi organik yang diperlukan memiliki kinerja baik.

\section{Kinerja Kinerja Penanganan}

\section{Pascapanen dan Pengolahan}

Kinerja subsistem penanganan \& pengolahan yang dibahas terdiri atas variabel bahan tambahan/penolong, sarana \& prasarana pengolahan, dan pemenuhan syarat umum mutu. Secara umum hasil kinerja subsistem ini berdasarkan perolehan indeks rataratanya dapat dilihat pada Gambar 3.

Berdasarkan Gambar 3 tersebut diketahui bahwa secara umum, total skor kinerja subsistem penanganan \& pengolahan berdasarkan perolehan indeks rata-rata pada Agribisnis Padi Organik binaan JAMTANI di Kabupaten
Pangandaran memperoleh tingkatan kinerja baik. Kinerja subsistem penanganan dan pengolahan terkait dengan pemberian bahan tambahan/ penolong lainnya menunjukkan kinerja sangat baik . Pada subsistem penanganan dan proses pengolahan gabah menjadi beras organik tidak pernah diberikan bahan tambahan/penolong untuk menjaga kualitasnya sehingga menunjukkan kinerja sangat baik dan untuk pengendalian hama dan penyakit serta pengawet makanan pun tidak pernah diberikan sehingga kinerjanya baik.

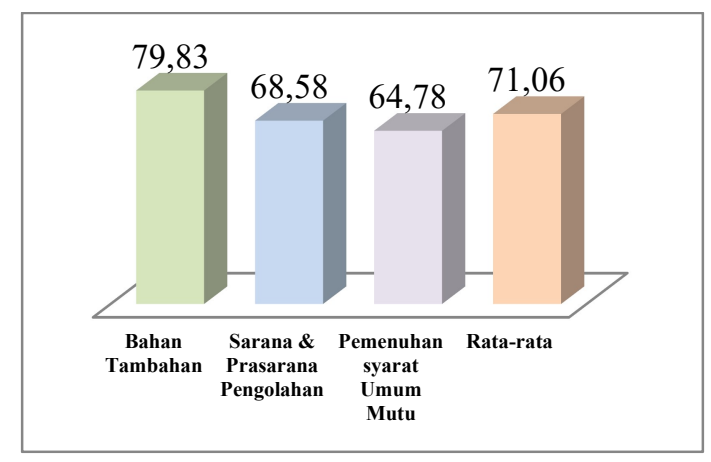

Gambar 3. Kinerja Subsistem Penanganan \& Pengolahan berdasarkan Perolehan Indeks Rata-rata Pada Agribisnis Padi Organik binaan JAMTANI di Kabupaten Pangandaran

Berdasarkan hasil perhitungan indeks rata-rata dapat dilihat bahwa kinerja subsistem penanganan dan pengolahan yang berhubungan dengan pemenuhan syarat umum mutu menunjukkan kinerja baik. Hal ini ditunjukkan dengan pemahaman petani bahwa agar beras yang dihasilkan terjamin kualitasnya maka perlu 
memenuhi syarat-syarat umum mutu dan hal ini menunjukkan kinerja sangat baik. Syarat umum mutu yang telah diketahui para petani dan petani dalam praktiknya sudah memenuhi syarat umum yang dipersyaratkan tersebut, kedua-duanya menunjukkan kinerja yang cukup baik.

\section{Kinerja Subsistem Pemasaran}

Kinerja subsistem pemasaran dibahas melalui indikator kemudahan pemasaran, sertifikasi, informasi pasar dan dihitung berdasarkan perolehan indeks rataratanya seperti dapat dilihat pada Gambar 4.

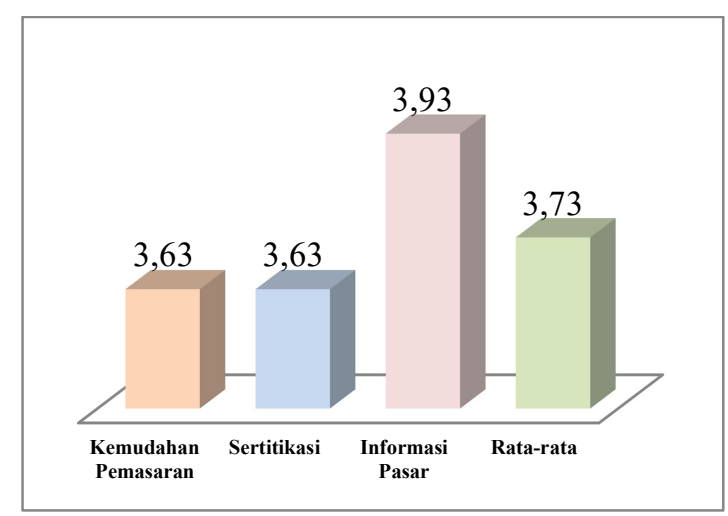

Gambar 4. Kinerja Subsistem Pemasaran berdasarkan Perolehan Indeks Rata-rata Pada Agribisni Padi Organik binaan JAMTANI di Kabupaten Pangandaran

Berdasarkan Gambar 4 tersebut diketahui bahwa secara umum, total skor kinerja subsistem pemasaran berdasarkan perolehan indeks rata-rata pada Agribisnis Padi Organik binaan JAMTANI di Kabupaten Pangandaran memperoleh tingkatan kinerja cukup baik. Dengan tingkatan kinerja cukup artinya masih menyimpan berbagai permasalahan pada subsistem pemasaran. Hal ini sesuai dengan yang disampaikan Mayrowani (2012), Ristianingrum (2015) bahwa kendala dalam pengembangan pertanian organik ada yang bersifat makro antara lain adalah kelembagaan pemasaran yang lemah, bersifat mikro diantaranya keengganan petani bertanam padi organik karena belum jelasnya pasar organik.

Salah satu penyebab petani terkadang mengalami kerugian adalah akibat fluktuasi harga padi organik yang tidak mereka ketahui, lainnya adalah minimnya informasi yang mampu diakses oleh para petani misalnya besarnya pangsa pasar, permintaan konsumen ekspor, dll. Sesungguhnya dalam era globalisasi dan keterbukaan informasi seperti saat ini, sebenarnya tidak terlalu sulit bagi petani untuk mengakses informasi tersebut dengan jaringan internet yang sudah menjangkau pelosok daerah dan akan sangat membantu. Hanya yang jadi permasalahan, sampai dengan saat ini masih sangat sedikit petani yang mau dan mampu mengakses informasi tersebut untuk mendukung aktifitas usaha tani mereka. Padahal kalau petani mau mengakses informasi tersebut, mereka akan dapat membuat perencanaan 
usaha tani dengan baik misalnya merencanakan luas tanam, jadwal dan pola tanam yang akan mereka lakukan. Dengan demikian, pada saat memasuki masa panen, tidak ada kesulitan bagi mereka untuk memasarkan produk pertanian yang mereka hasilkan. Akses informasi juga memungkinkan para petani dapat menjalin kerjasama langsung dengan para pelaku usaha di kota-kota besar tersebut, bahkan dapat menjalin kerjasama dengan para eksportir, sehingga harga jual yang mereka dapatkan akan jauh lebih meningkat, dibandingkan dengan menjual produk mereka melalui pedagang pengumpul mulai dari tingkat desa, kecamatan sampai kabupaten. Kenyataannya yang mau dan mampu mengakses informasi sangat terbatas dan kadangkala informasi tersebut hanya dimanfaatkan untuk kepentingan personal.

\section{Kinerja Subsistem Unsur Penunjang}

Kinerja subsistem unsur penunjang dilihat dari indikator kebijakan pemerintah, bantuan permodalan, penyuluhan dan pelatihan dan keberadaan Kelompok Tani. Penghitungan kinerja subsistem unsur penunjang berdasarkan perolehan indeks rata-ratanya dapat dilihat pada Gambar 5.

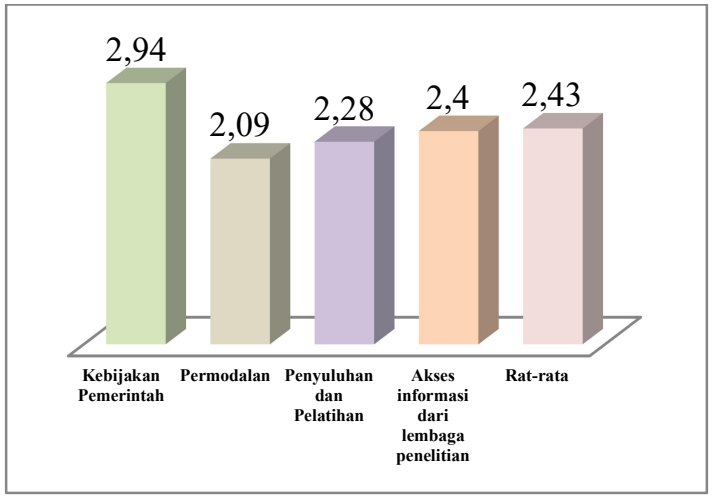

Gambar 5. Kinerja Subsistem Unsur Penunjang berdasarkan Perolehan Indeks Rata-rata Pada Agribisnis Padi Organik binaan JAMTANI di Kabupaten Pangandaran

Berdasarkan Gambar 5 tersebut diketahui bahwa secara umum, total skor kinerja subsistem unsur penunjang berdasarkan perolehan indeks rata-rata pada Agribisnis Padi Organik binaan JAMTANI di Kabupaten Pangandaran memperoleh tingkatan kinerja kurang baik. Di atas Kinerja Subsistem Unsur Penunjang (Kebijakan Pemerintah) memiliki kinerja yang cukup baik. Program-program pemerintah yang masih merujuk kepada program pemerintah pusat seperti Go-Organik dan setelah program selesai maka tidak ada kelanjutannya. Sebagai contoh di Kabupaten Ciamis, pada tahun 2009 telah dilatih sebanyak lebih kurang 75 orang untuk bertanam padi organik, namun sampai sekarang tidak berlanjut, dan para petani sebagian besar kembali lagi ke pertanian konvensional. Padahal program Go Organic 2010 dilaksanakan guna 
mewujudkan Indonesia sebagai salah satu produsen pangan organik terbesar di dunia (Departemen Pertanian, 2007 dan Litbang Pertanian, 2010). Program ini merupakan salah satu bentuk dukungan yang diberikan pemerintah untuk meningkatkan pertumbuhan produk organik yang ada di Indonesia, dengan harapan dapat meminimalisir isu-isu etikal penggunaan bahan kimia pada makanan yang membahayakan bagi kesehatan manusia.

Berdasarkan data yang dikumpulkan dan menurut responden petani yang diteliti, bahwa modal untuk biaya produksi padi organik lebih hemat dibanding dengan konvensional sekitar $30-40 \%$, meskipun begitu biaya produksi untuk budidaya padi organik terutama pengeluaran untuk biaya tenaga kerja pengolahan lahan yang memerlukan lebih banyak. Seperti pada umumnya petani padi di Indonesia, bahwa modal untuk biaya produksi padi organik di wilayah penelitian sangat terbatas dan para petani sangat mengharapkan bantuan, namun faktanya bahwa jumlah bantuan permodalan yang diberikan oleh berbagai lembaga keuangan sangat minimal dan aksesibilitasnya sangat minimal dan pada akhirnya para petani melaksanakan usaha taninya dengan hanya mengandalkan modal sendiri seadanya, meminjam ke petani yang lain atau ke koperasi yang ada di wilayahnya.

\section{KESIMPULAN DAN SARAN}

\section{Kesimpulan}

Berdasarkan pendekatan sistem agribisnis yang terdiri atas subsistem penyediaan input, budi daya, penanganan panen dan pascapanen, pemasaran dan penunjang menunjukkan bahwa kinerja agribisnis padi organik pada petani mitra JAMTANI di kabupaten Pangandaran memperoleh kinerja cukup. Perubahan produksi jika dilihat dari jumlah petani, sebanyak 120 orang pernah mengalami perubahan jumlah produksi.

\section{Saran}

Saran bagi lembaga untuk pengadaan benih juga dapat dilakukan melalui kerja sama dalam program terpadu antara kelompok tani, dinas pertanian sebagai penentu kebijakan. Kerja sama dilakukan dengan negosiasi antara tiga pihak sehingga dapat tercapai persetujuan yang memberikan manfaat bagi semua pihak.

\section{UCAPAN TERIMA KASIH}

Segala puji dan syukur penulis panjatkan kepada Tuhan Yang Maha Esa 
serta ucapan terima kasih kepada: 1)

Pengurus JAMTANI di wilayah Pangandaran yang telah banyak memberikan informasi yang dibutuhkan dalam penelitian ini, 2) Kepada project penelitian Climate Resilience Agriculture Investigationand Innovation Project (CRAIIP) selaku wadah yang telah memberikan dana kepada penulis dalam menyelesaikan Riset ini

\section{DAFTAR PUSTAKA}

Amaliah 2015. Permasalahan Dalam Pengembangan Pertanian Organik. Laporan. Jakarta

Kennerley dan Neely. 2002. A Framework of the Factors Affecting the Evolution of Performance Measurement Systems. International Journal of Operations \& Production Management. 22: 1222-1245.
Luthans, F. 2005. Organizational Behavior. New York: McGraw-hill. Mayrowani, Henny. 2012. Pengembangan Pertanian Organik di Indoneia. FORUM PENELITIAN AGRO EKONOMI, Volume 30 No. 2, Desember 2012 : $91-108$

Ristianingrum, Anita. 2016. Model Agribisnis Padi Organik di Kabupaten Cianjur Jawa Barat. Sekolah Pascasarjana Institut Pertanian Bogor. Bogor.

RPJMD Provinsi Jawa Barat Tahun 2013 - 2018. Provinsi Jawa Barat. Bandung.

Surekha K, Rao KV, Shobha Rani N, Latha PC, Kumar RM .2013. Evaluation of Organic and Conventional Rice Production Systems for their Productivity, Profitability, Grain Quality and Soil Health. Agrotechnol S11: 006. doi:10.4172/2168-9881.S11-006.

Sutrisno, Edy. (2016). Manajemen Sumber Daya Manusia. Jakarta: Kencana. 